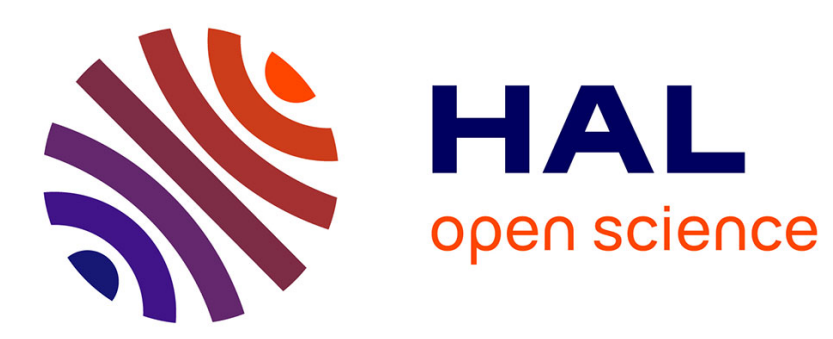

\title{
The benefits of the digital supply chain for horizontal resource pooling - the case of the Bio Loire Océan Farmers' Association
}

Virginie Noireaux, Joseph Edzengte Edzengte

\section{- To cite this version:}

Virginie Noireaux, Joseph Edzengte Edzengte. The benefits of the digital supply chain for horizontal resource pooling - the case of the Bio Loire Océan Farmers' Association. Supply Chain Forum: An International Journal, 2020, 21 (3), pp.196-205. 10.1080/16258312.2020.1754115 . hal-03420554

\section{HAL Id: hal-03420554 https://hal.science/hal-03420554}

Submitted on 9 Nov 2021

HAL is a multi-disciplinary open access archive for the deposit and dissemination of scientific research documents, whether they are published or not. The documents may come from teaching and research institutions in France or abroad, or from public or private research centers.
L'archive ouverte pluridisciplinaire HAL, est destinée au dépôt et à la diffusion de documents scientifiques de niveau recherche, publiés ou non, émanant des établissements d'enseignement et de recherche français ou étrangers, des laboratoires publics ou privés. 
The benefits of the digital supply chain for a collective strategy - the case of the Bio Loire OcéanFarmers'Association.

Noireaux Virginie $^{\mathrm{a} *}$ and J. Edzengte Edzengte $\mathrm{e}^{\mathrm{b}}$

${ }^{a}$ Research Center in Business and Management of Clermont-Ferrand EA 3849, France;

${ }^{\mathrm{b}}$ Research Center in Business and Management of Clermont-Ferrand EA 3849, France

*corresponding author:virginie.noireaux @uca.fr

Provide short biographical notes on all contributors here if the journal requires them.

Acknowledgements: We thank Audrey Milton for the time spent reviewing the document. 


\title{
The benefits of the digital supply chain for horizontal resource pooling: : the case of the Bio Loire OcéanFarmers'Association.
}

\author{
The aim of this paper is to highlight the benefit of the digital supply chain (DSC) \\ in resource pooling strategies of farmers. To do this, we will look at a strategy \\ for pooling resources used by those involved in organic farming $(\mathrm{OF})$. The case \\ of the Bio Loire Océan association demonstrates how the DSC allows organic \\ farmers to consolidate physical flows and information flows to respond to \\ increasing demand. Using the DSC makes it possible to enhance the pooling of \\ resources and to overcome some relational boundaries. This also makes it \\ possible to reduce the importance of the provider in the pooling of resources.
}

Key words: Digital supply chain, organic farming, area, pooling of resources.

Between 2000 and 2015, the number of organic farms multiplied by 9.6 times and the area cultivated by 3.3 times, on a global scale (Agence Bio, 2017). Data show that organic farming (OF) in France has experienced unprecedented growth for more than ten years (Agence Bio, 2018). In France, the area of agricultural land used for organic farming was estimated at 1.77 million hectares in 2017. Furthermore, almost 520,000 hectares are currently being converted to organic production. This growth can be explained by the high demand for organic products (15\% market growth in 2017) and by a better distribution of these products in the supply chains (SC): presence in local businesses, online supermarket shopping, hypermarkets and specialist shops.

However, analysis of the organic sector reveals a considerable imbalance between demand and supply capacities. Producers face various types of difficulties when responding to market need (Schieb-Bienfait and Sylvander, 2004; Bréchet and Schieb-Bienfait, 2006). These difficulties are of a structural, geographical and organisational nature. In terms of structure, organic certification limits the size of 
individual operations. This limit causes a dispersal of operations, and restricts volumes of production (Bréchet and Schieb-Bienfait, 2006). In terms of geography, the scattered and isolated character of farming operations increases response times and transport costs (Noireaux and Ralet, 2019). Lastly, in terms of organisation, digital tools are used rarely, or not at all, in the coordination of agricultural logistics chains (Büyüközkan and Göcer, 2017). The use of the digital tools, along with logistical resource pooling can be effective solutions to these difficulties. The size of the farm (limited by organic certification itself) does, in fact, limit production volumes, and dictates that individual producers use local distribution (such as direct sales). Furthermore, lack of digital tools is an obstacle to certain large markets, such as hypermarkets and supermarkets (Abbad et al., 2012).

Logistical pooling of resources is defined as "several independent businesses sharing their logistical activities" (Rouquet and Vauché, 2015). It is, therefore, a form of logistical cooperation between businesses. Information and communication technologies can strengthen logistical cooperation (Segars and Grover 1995; Dinter, 2013; Scuotto et al., 2017). The digital solution integrates systems and pools information. These two elements are the foundations for the success of logistical strategies (Korpela et al., 2016). As a tool for integrating systems, the digital supply chain (DSC) structures operational exchanges and improves communication between actors in the chain (Chen and Paulraj, 2004). Its objective is to build a steering platform to help pooling physical flows. This platform must take into account the needs and aims of each of its members. The DSC is currently used mostly by large companies (Dahlberg, Hallikas, Korpela, 2017; Büyüközkan and Göcer, 2017). The tool makes it possible for a company to integrate two or more partners (Setra, 2008). In the literature, while the benefits of using DSC in managing large companies is extensively covered, its 
use in logistical horizontal pooling of resources by small actors is not well-studied. This is the specific context of interest to us. More specifically, our aim is to understand what the DSC contributes to the pooling of resources by farmers. Therefore, we aim to respond to the following questions: to what extent does the DSC allow the implementation of logistical pooling of resources? Does the DSC allow certain limits of resource pooling to be overcome? First of all, we shall present the theoretical framework, namely logistical pooling of resources in the supply chain (SC). We shall then look at the role of the DSC for management of the SC. Secondly, we shall outline our methodology by looking at a single case study. Studying Bio Loire Océan (BLO), we will discuss the utility of the DSC for pooling of resources.

\section{Logistical pooling of resources}

Logistical pooling of resources involves sharing physical resources (warehouses, platforms, delivery vehicles, etc.), organisational means (logistic systems), but also the "data necessary for management" (Habbad et al., 2016). The aim is to improve the economic and environmental performance of the SC (Pan, 2010; de Corbière et al., 2010). Rouquet and Vauché (2015) propose a typology of logistical pooling of resources. They identify four types of resource pooling, depending on two factors: "Players identity" and "Decision process". The case studied in this paper corresponds to the type "club pooling": Some businesses from the same sector (farmers) decided to pool their logistical resources to make use of the same networks. Here we see horizontal cooperation between actors. In this case, although the businesses are competitors, it is in their interest to pool their logistical operations. More specifically, farmers' pooling strategies may look to coordinate production or commercialisation or to achieve specific standards (Laughrea et al., 2018). For the businesses, the challenge of this type of 
resource pooling is to agree on common rules. This mediation arises through a logistics service provider in their capacity as a neutral actor (Fulconis et al., 2011; Pan et al., 2014; Rouquet and Vauché, 2015).

The advantages associated with logistical pooling are numerous: reducing logistics costs (Frisk et al., 2010), decreasing environmental pollution (Pan et al., 2010), access to new markets (PIPAME, 2011) or even reconfiguring power relations between members of the supply chain (Noireaux and Poirel, 2014). In the more specific case of SMEs, pooling increases the business owner's ability to analyse his environment. Individually, it is difficult for the business owner to access information due to a lack of time, means, or organisation. Resource pooling makes it possible to overcome these difficulties through exchange of information or networking of actors (Meyer et al., 2017).

Although the advantages of resource pooling are numerous and clearly identified in the literature, its implementation seems difficult (Ruel, 2019). This is especially the case in the context of horizontal cooperation, where farmers, who are sometimes competitors, must cooperate.

Difficulties relating to technical aspects, such as the technical compatibility of oducts (chilled/frozen, organic/regular), volume (having sufficient volume to monetise resource pooling) and the location of participants (proximity sought) (Habbad et al., 2016 ; Habbad et Mahjoub, 2017 ; Ruel, 2019). In addition, lack of knowledge, IT resources or systems accounting is an important brake (Habbad et Mahjoub, 2017; Ruel, 2019). Difficulties can also be relational. For Noireaux (2015), organisational risks are linked to two factors: non-performance (not achieving the set goals) and relational risk (deterioration of relationships owing to difficulties in coordinating between individual logics and a collective logic). In literature, the risk is generally arbitrated by the logistics service provider (Rouquet and Vauché, 2015; Fulconis et al., 2011; Pan et al., 
2014 ; Habbad et Mahjoub, 2017 ; Ruel, 2019). The logistics service provider here is a neutral stakeholder who facilitates intermediation tasks. The logistics service provider's challenge is therefore to manage the strategic changes of the actors who pool flows (Fulconis et al., 2011). The instability of resource pooling is largely linked to difficulties in coordination between the individual strategy and the collective strategy (Ruel, 2019). Therefore, the inter-organisational framework that takes shape is cooperative by nature. The coopetitive approach may seem harsh and complicated (Habbad et Mahjoub, 2017; Ruel, 2019), as companies in the same industry are simultaneously rivals and partners, which raises the question of "balance" between cooperation and competition and therefore, that of the durability of the collective.

\section{The DSC for overcoming the limitations of resource pooling}

The surge in information and communication technologies has shaken up the structure of organisations and the structure of systems for exchange. Regardless of the term used, such as digital supply chain (Maier, Passiante, Zhang, 2011), e-logistics (Paché, 2008; Durand, 2009) or even company logistics information network (Gunasekaran and Ngai, 2005), the DSC appears like a complex and shape-shifting organisation. It makes heterogeneous and hierarchically independent actors collaborate. The DSC appears, therefore, to be an appropriate tool for pooling of resources that facilitates collaboration. Today, the integration of information and automation of services are an important part of the commercial value in supply chains (Neubert et al., 2016). Other indicators of this value are the levels of system integration and information pooling (Dinter, 2013). To follow the arguments of Gunasekaran and Ngai (2005), the DSC is founded on the development of a plan of action that is suitable for collectives. This plan of action includes four elements: (i) efficiently planning logistics flows; (ii) a close relationship with commercial partners; (iii) continued improvement in production processes and (iv) 
better organisation of circuits and distribution channels.

More specifically, literature on the DSC offers two contributions to pooling of resources. The first is linked to better synchronisation of flows. As a tool for integration, the DSC allows structuring operational exchanges and improving communication between actors in the chain (Chen and Paulraj, 2004). Its objective is to manage various flows through a digital platform. The platform shares data from a collective agreement (Edzengte, 2018). The electronic interface allows the integration of actors and the coordination of operations (Serve et al., 2002). In logistics, integration enables a better synchronisation of flows and improves the coordination and competitivity of the actors in the chain. 2000). In this way, the DSC appears as a special tool for improving the management of flows in resource pooling.

The second contribution brought to resource pooling by the DSC is that it can guarantee the autonomy of actors. The DSC actually offers a multi-party environment that takes into account different requirements and objectives. The electronic interfaces of the actors structure flows by synchronising physical flows into autonomous companies. The actors freely choose the flows that they want to pool and therefore, the ones that they integrate into the system. This desire to join a collective project while preserving the actors' autonomy requires rethinking with regard to building and developing collectives (Bréchet and Schieb-Bienfait, 2011). Creating and operating a system of this kind requires mastery of the interface mechanisms and the co-building of a global supply system (Paché, 2006). In this way, the DSC makes it possible to overcome certain limits of resource pooling, notably coopetition. In effect, being able to freely enter their flow in the system, actors are susceptible to maintaining the own competitive dynamics. This individual dynamic can also increase or decrease according to the needs of the actor. The loss of an individual competitive dynamic may lead to difficulties 
concerning profitability, especially in the context of small actors, who are, in some casesmore economically fragile and therefore more sensitive to fluctuations. The possibility of being free to manage the individual and collective part of flow enables problems linked with coopetition to be overcome. In addition, the DSC enables better synchronisation of flows and maintains a level of autonomy, so in this sense, it can overcome certain limits of resource pooling.

We shall now present our methodology and case study.

\section{Bio Loire Océan as a single case study}

Our objective is to understand what contribution the DSC makes to farmers' pooling of resources and as such it is an exploratory work, as the DSC are rarely used by participants in the agricultural sector (Büyüközkan and Göcer, 2017). The choice of the exploratory approach makes it possible to go back and forth throughout the research process (Chareire and Durieux, 2003). The case study is notable for its in-depth analysis of practices at the heart of a specific environment (Eisenhardl, 1989). It allows the understanding of a contemporary phenomenon (DSC in the agricultural sector) in a reallife context. The objective of the case study is to present the ensemble of the process, of identifying the resources, the activities and the actors that manage them (Yin, 2003). This choice of methodology allowes access to rich and varied data for in-depth analysis. The case in our case study is the BLO association (Bio Loire Océan). BLO pools farmers' flows and uses a DSC tool. BLO brings together more than 50 organic fruit and vegetable producers in the Pay de la Loire region in France. The farmers created the association to strengthen their supply capacity (volume, quality, turnaround time), faced with a growing market. The farmers built a digital tool allowing then to organise the pooling of resources. We had access to the site between 2015 and 2018. We interviewed four key actors in the process: two leaders (the president of the association and the 
coordinator), a farmer and an important client (BIOCOOP group ${ }^{1}$ ). The interview guide was structured in four parts: (1) the description of the organisation which supports this pooling of resources (governance, activities...); (2) the structure of the logistical network (flow mapping, actors, circuits...); (3) the technical dimension of the computerised tool (technology used, software platform, interface, EDI...); (4) access to and use of the computerised tool (utilisation, information exchanged, level of collaboration, obstacles...). The four interviews, lasting an average of 50 minutes, were recorded and transcribed. This data was supplemented by using internal documents (specifications, charters, activity reports...) and using notes from non-participant observations during 12 visits to farmers and six coordination meetings. Through this data collection, we have obtained 192 pages of information for analysis. We have processed this data using the software QSR Nvivo 8.0. This analysis made it possible to identify individual and collective practices and the benefits of the digital platform.

\section{BLO Case presentation}

The BLO association was created in 1997, driven by a quarantine placed on agricultural farmers. Its aim was to unite actors in the sector in order to pool flows in the context of significant and growing demand.

"This association came about as a result of a desire to organise the profession in the face of growing demand by supermarkets and hypermarkets for organic fruit and vegetables. Our desire was to be present together, using the same language, with the aim of responding quantitatively and qualitatively to this new market. In order to be a credible voice to our clients, it was necessary to come together and pool both our technical and commercial experience." (President)

\footnotetext{
${ }^{1}$ Biocoop is a cooperative society in limited company form with variable capital, specialised in the commercial distribution of food products labelled $\mathrm{AB}$ (for Agriculture Biologique, organic farming), Bio Cohérence (a French association providing organic certification), Demeter (an international association providing organic certification) etc; and fair trade products, eco-products and cosmetics. In 2019, its network is made up of more than 500 shops, scattered over the whole of France and is affiliated with Synadis Bio, a union that brings together shops specialised in organic food.
} 
In order to structure itself, the association received support, between 1997 and 2004, from the Association of Organic Farmers (Groupement d'Agriculteurs Biologiques GAB) and the Regional Management for Food, Agriculture and Forestry. This structuring was requested and supported by BIOCOOP. This resulted in building a resource pooling logistics platform. The pooling of resources relates to production flows and marketing of organic fruit and vegetables in France. At this stage, resource pooling was managed by fax.

"The business relationship with BIOCOOP has been a catalyst. The organisation did not want to receive 50 phone calls from 50 producers from the same sector. We had to make a joint bid. From that moment, we worked to implement a centralised supply platform while taking care to preserve the independence of the producers, who had been accustomed to managing everything by themselves." (Coordinator).

In 2009, this platform was strengthened by the digitisation of information handling, exchanging and sharing processes between actors. This computerised tool enabled better logistical flows and preserved the autonomy of the actors.

"The tool has allowed producers to operate as a network by regularly sharing information about products, quality, prices, orders and deliveries to clients. The producers have day-to-day knowledge of availability of products. The tool allows each producer to announce quantities and participate in daily buying sessions alongside clients such as BIOCOOP, the catering sector, supermarkets and hypermarkets." (Coordinator)

Today this IT tool is controlled by all the farmers of BLO who use it daily. The IT tool makes it possible to create a communal offer online. It also allows farmers to have informal and frequent information exchanges. This has resulted in complete transparency between producers with regard to quantities, prices applied and demand.

"In this notion of transparency, both for the clients and the producers, it's possible through the order interface for everyone to see who's offering what and at what price. It's complete transparency of business practice. One single interface for all the producers and clients. There can't be any opportunistic 
behaviour. The tool and its interface regulates conduct and fosters trust between producers." (BIOCOOP)

The IT tool, which was developed internally by BLO, today seems to be a lever for better synchronisation of the logistic flows in resource pooling.

\section{Research findings}

\section{The DSC as a tool for pooling flows}

BLO's approach to pooling flows is structured in four parts: (1) improving production practices; (2) better organisation of circuits; (3) planning; and (4) a close relationship with clients. These four points correspond to those proposed by Gunasekaran and Ngai (2005), and correspond to the action plan on which the DSC is based.

\section{- Improvement of production practices: specifications and standardisation}

Standardising the offer required the establishment of a common policy in terms of production. BLO has compiled specifications that enable standardisation in production practices (cultivation of fruit and vegetables). This desire for standardisation makes the flow standard and facilitates pooling. Writing of specifications has been a difficult stage, but it has allowed for discussion about practices between actors. The discussions have dealt with technical aspects, especially the impacts and limits on individual practices. These discussions have resulted in standardisation of practices and control indicators. The association was also aided by the specifications of organic agencies (Bio Cohérence, Biobreizh, Bio Suisse, Demeter, Nature et Progrès, etc.) and several charters (charter of a socially responsible company). BLO also brought in specialised organisations for process control and researchers from different fields.

"BLO's own specifications play the role of harmonisation of behaviours within the association. An audit of the farms was carried out by accredited certifier CERTIPAQ in 2014, followed by the first inspection in 2015. This experimental study made it possible to confirm the common foundation of non-negotiable principles and the margin of tolerance on other points." (BLO member)

All the association members now adhere to the specifications, even those who do not conduct trade through the network. This approach resulted in the BLO network being 
given a label recognised by the National Platform for Fair Trade (Plateforme nationale du Commerce Equitable - PFCE).

\section{- Circuit organisations: homogenisation of packaging and packing lists}

Packaging has a key role in the process and shipping goods. In fact, flow pooling demands a certain harmony in the presentation of products. Each type of packaging must have the same standards: height, width, length and weight. This standardisation contributes to the storage of packages and the optimal management of transport capacity.

"The purpose of this collective analysis was to give a common image to our supply. It resulted in the development of standards for the size of different products as well as the presentation of packaged products before every dispatch." (BLO member).

BLO farmers now use uniform packaging and have mastered techniques of batch packing lists and weight. This mastery allows easy referencing of products, use of uniform labels, and palletising and loading onto transportation vehicles.

\section{- Participatory planning of quantities}

For BLO, the objective of planning is to prevent all farmers from producing the same products at the same time. The total production volume (across the pool) must correspond to the actual market demand. The association looks to adjust the quantities available according to fluctuating demand, and to what products are in season.

To regulate supply, the producers agree on who produces what. How much? In what time scale? For which market? Each member is committed to the varieties produced, the period of availability (the harvest), and the forecast quantities. These elements are lodged by each member on the digital platform. The system then consolidates flows. Lastly, for each period (year, quarter, month, week), a single screen provides a list of items that are potentially available, as well as quantities and prices.

\section{- Close relationship with the customer: centralising orders and dispatches}

Once the planning schedule has been approved by the farmers, the association passes this on to the customers. They can then make orders through the platform or directly 
through the producer. Pooling flows is a necessity when the volume ordered requires gathering the harvests of two or more farmers. The association structures the organisation for pooling flows. It uses meeting points, which are temporary locations for centralising and redirecting flows.

"There was a lot of thought put into the organisation of logistics for delivering the product to the client, with producers not wanting to have a physical platform that pools all of their goods for reasons relating to cost, geographic scattering, freshness and the sensitivity of the products." (President).

The farmers chose to put in place temporary gathering points that are decentralised and based within production areas. In each sector, in a radius of $30 \mathrm{~km}$ to $40 \mathrm{~km}$, some farmers make their refrigerators and platforms available to hold goods from other producers that are needed for an order. The actor arrives at the meeting point with the packages and individual batches are consolidated in a group. Then there is the unpacking and repackaging stage for some parcels, if required. At the end of the operation, the goods are given to a service provider who is responsible for transporting them to the relevant customers.

\section{The DSC for maintaining autonomy}

The products offered by the BLO farmers have the same technical characteristics and are traded in uniform packaging, with the same label and at the same price.

To reach a single price, there is a need to determine costs according to the specific features of each operation (size, soil fertility, etc.). This is because not all the producers cultivate the same areas of land and therefore have different levels of productivity. To resolve this, the farmers have set up a compensation system. The market price (single price for the customer) is set by calculating the various costs for farmers. However, prices fluctuate due to variations in market mechanisms (whether the product is in season, quantity of supply, etc.). The price set is generally the result of consensus between producers. The lower limit of prices is usually set during the General Meeting (GM) to avoid tension. However, interpersonal exchanges continue outside this framework between the producers concerned with an order. These uninterrupted exchanges relieve tensions and encourage a consensus on price. This process always 
takes into account social (properly paid workforce, principles of solidarity, working conditions) and commercial (fair price according to the market) criteria.

Centralised invoicing has been the basis for structuring the association.

"This initiative was launched in May 2004 when BIOCOOP and BLO signed an agreement in which the platform for BIOCOOP shops asked members of the association to centralise individual invoices and to send them one invoice that shows the consolidated and delivered batch. We started with fax, but digital tools have now made this an automated operation." (President).

Invoicing is carried out in two stages: the producer invoice, which is followed by the collective invoice. (1) In the "producer invoice", each actor issues an invoice that is sent to the association's coordinator. (2) A "collective invoice" that gives the batch purchased by the customer is issued by the BLO coordinator.

\section{- The DSC for linking together individual and collective capacities}

The DSC is a tool that serves to pool the resources of farmers. Each BLO farmer notes their supply online every day and receives orders. However, there is no obligation to use the DSC: each producer has the option to have customers outside BLO and to supply their products with other supply chains.

There is central coordination for structuring pooling The association has a full-time employee (coordinator) to manage the tool. This coordinator analyses the combined data and organises the gathered sales. The producers operate as a network by regularly sharing and exchanging information about products, quality, prices and orders, etc.

Figure 1: Structuring the BLO project around the DSC 


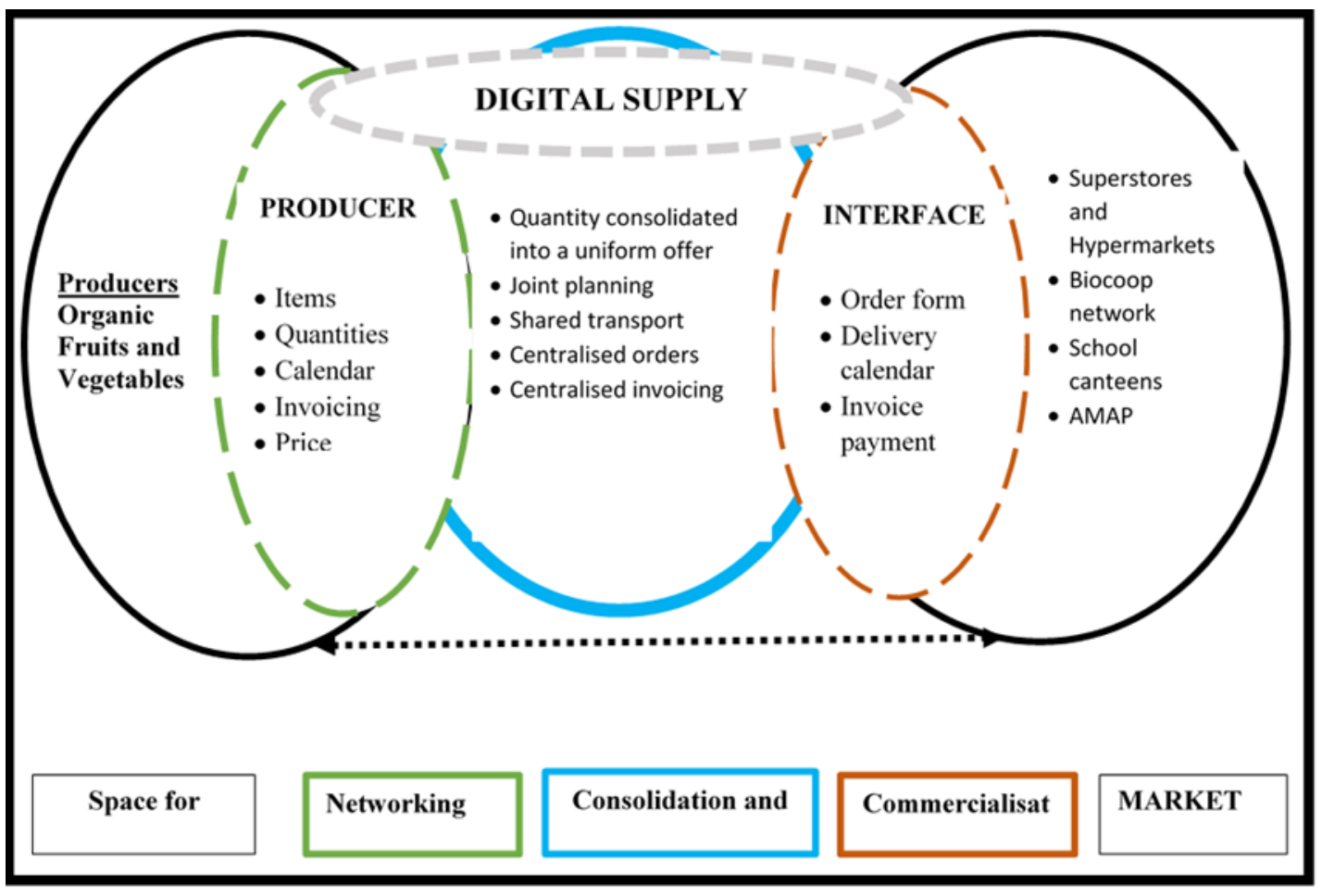

The IT tool developed makes it possible to create a communal online offer without stopping informal and frequent exchanges of information between producers. The DSC reinforces transparency within transactions and, with the ordering interface, makes it possible to view what products are on offer and their prices. This allows the customer to have one interface for shopping. The structure of BLO's DSC project is given in diagram 1. In addition, the DSC regulates conduct, which enables trust between the producers.

\section{Discussion}

The results highlight three elements, which are discussed in this section: the specific features of pooling resources in the organic farming sector, the DSC and relational risks and the DSC as a tool for limiting the role of the service provider.

\section{Specific relational and technical features of pooling resources in organic farming}

\section{flows}

Organic farming is evolving in a context marked by the imbalance between what is on offer (limited supply) and demand (large volumes). Resource pooling has been developed by actors in the logistics chain to consolidate the supply and to share transport. In the case of BLO, warehousing operations are not included in the pooling of resources, which can be explained by two factors. The first is linked to the nature of the 
product. This is because some foodstuffs (salads, etc.) are highly perishable and must be managed in strict flows. The second is linked to the organisation of farmers: foodstuffs that can be stored (potatoes, etc.) are generally kept at the farm. Farmers are not usually concerned about a lack of space. Setting up a warehouse by the organisation would add an additional cost without providing added value.

The BLO pooling of resources has had a strong relational aspect from the beginning: the party placing the order (BIOCOOP) wants to have a single point of contact. Here, it is the party placing the order who initiates the process. From a relational perspective in the supply chain, the party placing the order leads to structuring the farmers' offer and therefore, to their increase in capacity. This situation is counter-intuitive, in comparison to the literature. In the studies that deal with the appearance of resource pooling, two factors are generally put forward by the authors. It is either the overlooked companies that come together to counter the capacity of a strong partner (Noireaux and Poirel, 2014), or it is the party placing the order who initiates the pooling of resources, but keeps control of operations (Livolsi and Camman, 2012). The specific situation of BLO can be explained by two factors. The first is linked to the nature of the supply chain. Supply chains for "organically farmed products" promote values that are strongly linked to sustainable development. For example, the BIOCOOP brand promotes "a commercial relationship based on transparency..., solidarity..., fairness and respect..."2. Applying these principles therefore leads to balancing the strength of connections. Another explanation can be found in the growth of the organic market. It has seen double-digit growth of $18 \%$ in 2017 and $15.7 \%$ in $2018^{3}$. This strong progress has led to the distributor developing the system of its trade network, to the detriment of controlling upstream operations. In addition, the DSC makes it possible to announce and organise daily, weekly or one-off sales sessions, depending on planning. It must be emphasised that in this industry, planning continues to be very theoretical. This is due to the fact that production is subject to considerable uncertainties: weather, diseases, etc. (Van der Vost et al. 2009). The tool therefore has to be updated regularly $n$ keeping with these limitations.

Pooling resources allows farmers to put forward a communal offer under the BLO label. We shall now present to what extent the DSC makes it possible to limit the relational risks linked to pooling resources.

\footnotetext{
${ }^{2}$ Website: https://www.biocoop.fr/Biocoop/Histoire-et-valeurs

${ }^{3}$ According to Agence Bio: https://www.agencebio.org/vos-outils/les-chiffres-cles/
} 


\section{The DSC for limiting the relational and technical risks of pooling resources}

The DSC makes it possible to optimise deliveries by taking part in a three-fold modification of flows. (1) Modifying volumes in a specific context in which unit quantities per producer do not meet the needs of large orders. (2) Modifying deadlines in a context defined by urgency (freshness of fruit and vegetables) with regard to the nature of the products and increased risks of becoming spoiled. (3) Modifying spaces for collection and delivery through a system of pooling transport and optimising cargoes. In this respect, the DSC is a genuine tool for pooling resources. It allows actors to benefit from the advantage of reduced logistics costs (Frisk et al., 2010) and of access to new markets (PIPAME, 2011).

The case of BLO makes it possible to organise the individual processes of farmers and the collective strategy of pooling resources. The DSC is a digital platform that allows for shared management. Its ability to simultaneously and interactively manage intracompany and inter-company subsystems enables the creation of an "added value logistics network" (Tang-Taye and Picard, P., 2000). The DSC takes into account different requirements and objectives and provides the option for each actor to get involved in the collective while maintaining their autonomy. Maintaining individual processes (through the choice of whether or not to offer the flows produced in the tool) is one of the factors key to the success of pooling resources (Chen and Paulraj, 2004).

The DSC also allows for permanent and continuous interpersonal exchanges. Paulraj et al. (2008) consider inter-organisational communication to be a critical factor in collaboration between actors. In addition, sharing information is not enough for an effective logistics chain, as trust also needs to be established (Kwon and Suh, 2005). The information exchanged focuses on quality management, production processes, setting prices, planning production and transport. The agricultural population is subject to relative psychological and physical isolation (town/countryside divide, image of "country folk" in the collective unconscious, distance of farms, etc.). This isolation explains the psychological struggles for farmers (Spoljar, 2015) and highlights the importance of social relations, from both within and outside the industry (Le Velly et al., 2016). In this respect, the DSC makes it possible to create links between actors who are relatively isolated, beyond logistics. 
In addition, even if the DSC has a multi-interface structure, the central coordination of flows makes it possible to bring together the offer proposed. This unification is not just a "simple addition" of the various original flows. It also focuses on organisational aspects (standardisation of production, homogenisation of prices, joint planning of flows and pooling transport resources). The importance of the organisational aspects of resource pooling has already been highlighted several times by researchers (Pan et al., 2014; Rouquet and Vauché, 2015; Büyüközkan and Göcer, 2017).

\section{The DSC - a tool limiting the role of the provider}

In the literature on logistics, the role of the logistics service provider (LSP) is a key factor in the success of approaches to horizontal pooling (Fulconis et al., 2011; Pan et al., 2014; Rouquet and Vauché, 2015; Habbad and Mahjoub, 2017; Ruel, 2019). The LSP makes it possible to facilitate the exchange of information regarding logistics, to reach the critical size, to have mediation on cooperation and to acquire expertise in managing flows. Some authors go even further to associate horizontal pooling with the systematic use of an LSP (Pan et al., 2014). However, our results counter the role played by LSPs as given in the literature. In the case studied, the LSP only had a simple transport-related role. The DSC makes it possible to limit the mediation of LSPs. We put forward two kinds of explanation: one is technical and the other is organisational.

The technical aspects of pooling are rather simple in the supply chain for "organically farmed products". In the case studied, cooperating companies are in a limited geographical area (Pays de la Loire) and have products with the same characteristics for transport (fresh fruit and vegetables), which makes pooling resources easier (Abbad et al., 2016 ; Habbad et Mahjoub, 2017). In addition, actors in the industry do not generally have issues with storage capacity. In fact, products are either very perishable and are only stored by cross docking, or they can be stored, generally loose, right with the producer. The tasks to be completed are standardised and made accessible to farmers (measuring products, packaging, labelling and loading onto pallets, etc.).

The organisational aspects of pooling, particularly the role played by the DSC, also results in diminishing the role of the provider. The barriers related to the lack of means, knowledge and accounting of IT systems (Habbad and Mahjoub, 2017; Ruel, 2019) are 
not identified in our case. Then the DSC allows actors to exchange a variety of information in real time. This makes it possible for actors to coordinate themselves through mutually agreed adjustments. This adjustment concerns planning, organising transport and prices. In addition, with regard to the products on offer, it must be remembered that the use of the DSC is optional. A farmer can have stock that is not made available through the DSC. If the individual market does not succeed, they can always join the system at a later date. We have identified few problems with regard to prices: prices for farmers are set according to different criteria (size of farms, specific features of agricultural land, etc.) that have been taken into account. Farmers then choose whether or not to enter the SC based on these prices.

In addition, the relatively simple technical aspects of pooling resources reduce the role of the provider. Furthermore, use of the DSC allows actors to make decisions through mutually decided adjustments. It should be noted that these adjustments are certainly possible because there is a strong demand for products in this context. When the market reaches maturity, it is possible that pressure on prices (transport, production, etc.) will lead to tensions between members. It may then become more difficult for them to achieve this mutual adjustment.

\section{Conclusion}

Pooling flows from different companies makes it possible to access many more physical tools, knowledge and markets. The objective of this article was to highlight the benefit of the digital supply chain (DSC) in the horizontal pooling of small actors. The case of the Bio Loire Océan association demonstrates how the DSC allows actors to consolidate the supply of organic food to give a unified response to an increasing demand for organic fruits and vegetables in the Pays de la Loire region. In this case, the implementation of the DSC is presented as a tool for consolidating the pooling of resources. Its operation required a transformation in production and exchange practices. The theoretical benefits of this research are organised into two types. The first is linked to the relational theories of the supply chain. In fact, in a context of growing SC and ethics, it would seem that actors are looking for balanced relationships. Our results show that the party placing the order through the process is not looking to master or control resource pooling. However, even if pooling resources simplifies purchases, it is also a source of considerable capacity for farmers who have more scope to establish 
their conditions. The second is linked to reducing the role of the LSP in the horizontal pooling processes managed by the DSC. In the case that we studied, the DSC allows actors to make mutual adjustments. In a market characterised by strong growth, the DSC makes it possible for actors to intercede in relationships and therefore be a "neutral player" that mediates pooling. The provider then becomes a simple transporter on behalf of farmers.

From a managerial perspective, the DSC appears to be a real asset in pooling the flows of small companies. Its construction can allow the actors to structure local (individual strategy) and collective dimensions. Going beyond the concerns regarding the autonomy of actors, the DSC represents a real key factor for the success of pooling resources.

This is an exploratory study, which implies that there are multiple limitations and potential research paths. A first limitation is linked to the specific characteristics of the agricultural and organic sector. In addition, there is a need to study the role of the DSC in narrow contexts (strong growth and ethics), such as that of producing organic cotton. Moreover, the results obtained must also be confirmed by studying another case. This process is currently underway and forms the continuation of our studies.

\section{References}

Abbad, H., Senkel, M. P., \& Dari, L. 2012. Understanding the non-adoption of EDI in the modern Moroccan food retailing industry. Supply Chain Forum: An International Journal. 13(3) : 82-91. doi : 10.1080/16258312.2012.11517300.

Abbad, H. \& Mahjoub, S. 2017. Logistics Pooling in the French Food Retailing Supply Chain : an Exploratory Study. Halshs-01548760.

Agence Bio. 2017. La Bio dans le monde, Les carnets de l'agence Bio. https://www.agencebio.org/wp-content/uploads/2018/10/carnet_monde_2017.pdf 
Agence Bio. 2018. Baromètre de consommation et de perception des produits biologiques en France, Agence BIO/CSA Research, Febuary. https://www.agencebio.org/wp-content/uploads/2019/02/AgenceBio-DossierdePresseBarometre2019.pdf

Bréchet J.-P., Schieb-Bienfait N. 2006. Projets et pouvoirs dans les régulations concurrentielles : la question de la morphogenèse d'une filière d'agriculture biologique, Revue d'Economie Industrielle 113 : 1-20. doi : 10.4000/rei.233.

Bréchet J.-P., Schieb-Bienfait N. 2011. Logique d'action et projet dans l'action collective ; réflexions théoriques comparées, Revue Finance, Contrôle, Stratégie, 14(1), 101-129. hal$00421180\rangle$.

Büyüközkan, G., \& Göçer, F. 2018. Digital supply chain: literature review and a proposed framework for future research. Computers in Industry. 97 :157-177. doi : 10.1016/j.compind.2018.02.010.

Charreire, S., \& Durieux, F. 2003. Explorer Et Tester: Deux Voies Pour La Recherche. Méthodes de Recherche en Management. 2nd ed. pp. 57-81. Paris: Dunod.

Chen I. J., and Paulraj A. 2004. "Understanding supply chain management: critical research and a theoretical framework," Int J Prod Res, vol. 42, pp. 131-163. doi : 10.1080/00207540310001602865.

De Corbière, F., Durand, B., \& Rowe, F. 2010. Effets économiques et environnementaux de la mutualisation des informations logistiques de distribution: avis d'experts et voies de recherche. Management Avenir. 39(9): 326-348. doi : 10.3917/mav.039.0326. 
Dinter B. 2013. Success factors for information logistics strategy: An empirical investigation. Decis. Support Syst. 54 :1207-1218. doi : 10.1016/j.dss.2012.09.001.

Durand B. 2009. Mutations logistiques de la cyber-épicerie française : quand les groupements d'associés défient la distribution intégrée. Logistique \& Management. 17(2) : 51-64. doi : 10.1080/12507970.2009.11516920.

Edzengte J. 2018. Gouvernance des flux logistiques en contexte d'économie circulaire. Le cas des acteurs de la filière bioalimentaire en France et au Cameroun. Thèse de Doctorat, Université de Nantes.

Eisenhardt, K. M. 1989. Building theories from case study research. Academy of management review. 14(4) : 532-550. doi : 10.2307/258557.

Frisk, M., Göthe-Lundgren, M., Jörnsten, K., \& Rönnqvist, M. 2010. Cost allocation in collaborative forest transportation. European Journal of Operational Research. 205(2): 448-458. doi :10.1016/j.ejor.2010.01.015.

Fulconis, F., Hiesse, V., \& Paché, G. 2011. The 3PL Provider as Catalyst of Coopetitive Strategies-An Exploratory Study. Supply Chain Forum: An International Journal. 12(2) : 58-69. doi : 10.1080/16258312.2011.11517260.

Gunasekaran A., Ngai E. 2005. "Build-to-order supply chain management: a literature reviewand framework for development". Journal of Operations Management. 23(5) : 423-51. doi : 10.1016/j.jom.2004.10.005.

Hicham Abbad, Bruno Durand, Marie-Pascale Senkel. 2016. Chapitre 3: La mutualisation physique et informationnelle en logistique. In «Organisation Information et Performance », ed. F. Meyssonnier et F. Rowe, Editions PUR. 
Korpela, K., Hallikas, J., \& Dahlberg, T. 2017. Digital supply chain transformation toward blockchain integration. Conference: Hawaii international conference on system sciences (HICSS), At Big Island, Hawaii, January 2017. Volume 50http://dx.doi.org/10.24251/HICSS.2017.506.

Kwon, I.W. G., \& Suh, T. 2005. Trust, commitment and relationships in supply chain management: a path analysis. Supply Chain Management: An International Journal. 10(1) : 26-33. doi : 10.1108/13598540510578351

Laughrea S., Mundler P., \& Royer A. 2018. Les coopératives alimentaires en circuits courts. RECMA. 347(1) : 111-127. doi : 10.3917/recma.347.0111.

Le Velly, R., Dufeu, I., \& Le Grel, L. 2016. Les systèmes alimentaires alternatifs peuvent-ils se développer commercialement sans perdre leur âme? Analyse de trois agencements marchands. Économie rurale [en ligne]. (6): 31-45. doi : 10.4000/economierurale.5046.

Livolsi L., Camman C. 2012. La mutualisation logistique dans le canal de distribution : une stratégie de contournement de la Loi de Modernisation de l'Economie. Management \& Avenir. 52(2): 99-118. doi : 10.3917/mav.052.0099. URL : https://www.cairn.info/revue-management-et-avenir-2012-2-page-99.htm

Maier R., Passiante G., Zhang S. 2011. "Creating value in networks", International Journal of Innovation and Technology Management. 8(03) : 357-371. doi : 10.1142/S0219877011002416.

Meyer, M., Narjoud, S., \& Granata, J. 2017. When collective action drives corporate social responsibility implementation in small and medium-sized entreprises: the case of a network of French winemaking cooperatives. International Journal of 
Entrepreneurship and Small Business. 32(1/2): 7-27. doi : 10.1504/IJESB.2017.10002073.

Morana J., Paché G. 2000. Supply Chain Management et tableau de bord prospectif : à la recherche de synergies. Logistique \& Management. 8(1):77-88. doi : $10.1080 / 12507970.2000 .11516725$.

Neubert, G., Ouzrout, Y., \& Bouras, A. 2004. Collaboration and integration through information technologies in supply chains.International Journal of Technology Management, 28(2), 259-273. doi : 10.1504/IJTM.2004.005065.

Noireaux V., Poirel C. 2014. Contrepouvoir et stratégies collectives : comment contrer le pouvoir d'un puissant partenaire dans le canal de distribution ?. Revue Française de Gestion. 243(40) : 81-95. doi : 10.3166/RFG.240.81-95.

Noireaux, V. 2015. Facteurs de risque des stratégies collectives entrepreneuriales : trois études de cas longitudinales (2002-2011). Revue internationale P.M.E. 28(1) : 87-116. doi : $0.7202 / 1030481$ ar.

Noireaux, V., \& Ralet, P. 2019. Difficultés des canaux de distribution alimentaire en territoire rural: l'importance du leader. Economie Rurale. 369(3): 21-39. doi : 10.4000/economierurale.6918.

Paché G. 2006. Approche spatialisée des chaînes logistiques étendues-de quelle(s) proximité(s) parle-t-on ?. Les Cahiers Scientifiques du Transport. 49: 9-28. https://afitl.msh-lse.fr/tl_files/documents/CST/N49/Pache49.pdf. 
Paché G. 2008. Efficient Urban e-Logistics: Mutualization of Resources and Source of Competitive Advantage, 7th International Meeting for Research in Logistics, Avignon, (France), September 24-26.

Pan, S. 2010. Contribution à la définition et à l'évaluation de la mutualisation de chaînes logistiques pour réduire les émissions de $\mathrm{CO} 2$ du transport: application au cas de la grande distribution (Doctoral dissertation).

Pan, S., Ballot, E., Fontane, F., \& Hakimi, D. 2014. Environmental and economic issues arising from the pooling of SMEs' supply chains: case study of the food industry in western France. Flexible Services and Manufacturing Journal. 26(1-2) : 92-118. doi : 10.1007/s10696-012-9162-3.

Paulraj, A., Lado, A. A., Chen, I. J. 2008. Interorganizational communication as a relational competency: Antecedents and performance outcomes in collaborative buyersupplier relationships. Journal of Operations Management. 26: 45-64. doi : 10.1016/j.jom.2007.04.001.

PIPAME. 2011. Pratiques de logistique collaborative: quelles opportunités pour les PME/PMI?, http://www.industrie.gouv.fr/p3e/etudes/logistique-collaborative/logistiquecollaborative.pdf

Rouquet, A., \& Vauché, L. 2015. A typology of logistics pooling in supply chains. Supply Chain Forum: An International Journal. 16(2) : 2-12. doi : $10.1080 / 16258312.2015 .11673825$.

Ruel, S. 2019. Freins à la mutualisation horizontale : enseignements d'une étude de cas dans le secteur agroalimentaire. Logistique \& Management. 27-2: 119-131, doi: 10.1080/12507970.2019.1597647. 
Schieb-Bienfait N., Sylvander B. 2004. Filière biologique et logique d'action: éléments d'analyse des difficultés de structuration d'une filière régionale. Conférence de l'Association Internationale de Management Stratégique (AIMS). Le Havre.

Scuotto, V., Santoro, G., Bresciani, S., \& Del Giudice, M. 2017. Shifting intra- and inter- organizational innovation processes towards digital business: an empirical analysis of SMEs. Creativity and Innovation Management. 26(3): 247-255. doi : 10.1111/caim.12221.

Serve M., Yen D. C., Wang J.-C. 2002. B2B enhanced supply chain process: toward building virtual enterprises. Business Process Management Journal. 8(3) : 245-253. doi : $10.1108 / 14637150210428952$.

Setra (2008), La logistique de la grande distribution, Note de synthèse, SETRA, Paris. https://observatoireprixmarges.franceagrimer.fr/Lists/Liste\%20des\%20etudes\%20autres/Attachments/57/O RSINI_2008.pdf.

Spoljar, P. 2015. Modernisation de l'agriculture et santé mentale: les contradictions au travail. Perspectives interdisciplinaires sur le travail et la santé [en ligne]. 17(1). URL : http://journals.openedition.org/pistes/4430. doi : 10.4000/pistes.4430.

Tang-Taye, J. P., \& Picard, P. 2000. Système d'information et supply chain management: rôle d'un prestataire de services logistiques. Logistique \& Management. 8(2) : 17-27. doi : 10.1080/12507970.2000.11516730 
Van der Vorst, J. G., Tromp, S. O., \& Zee, D. J. V. D. 2009. Simulation modelling for food supply chain redesign; integrated decision making on product quality, sustainability and logistics. International Journal of Production Research. 47(23) : 6611-6631. doi : 10.1080/00207540802356747.

Yin, R. 2012. Case study research: Design and methods (3nd ed.). Beverly Hills, CA: Sage Publishing. 